\title{
Avibacterium paragallinarum
}

National Cancer Institute

\section{Source}

National Cancer Institute. Avibacterium paragallinarum. NCI Thesaurus. Code C86158.

A species of facultatively anaerobic, Gram negative, coccobacilli shaped bacteria assigned

to the phylum Proteobacteria. This species is catalase negative and produces acid from

D-mannitol and D-sorbitol. A. parag allinarum is pathogenic in birds causing upper respiratory infections such as infectious coryza. 